\title{
Da invenção e do tesouro, como modos de adquirir a propriedade móvel.
}

\author{
Washington de Barros Monteiro \\ Catedrático de Direito Civil da Faculdade de \\ Direito da Universiadde de São Paulo.
}

O Código Civil Brasileiro disciplina separadamente os modos de aquisição da propriedade imóvel e os modos de aquisição da propriedade móvel.

Segundo o artigo 530, adquire-se a propriedade imóvel pela transcrição do título de transferência no registro de imóveis, pela acessão, pelo usucapião e pelo direito hereditário (ns. I a IV).

Por outro lado, adquire-se a propriedade móvel pela ocupação, pela especificação, pela confusão, comistão e adjunção, pelo usucapião e pela tradição.

De acôrdo com a ordem prescrita pelo legislador, surge, em primeiro lugar, a ocupação, que, aliás, do ponto de vista histórico, é de fato o primeiro e o mais importante de todos os modos de se adquirir o domínio: nas origens da sociedade.

Define-a SÁ Pereira (Manual, 8/331), como a posse que afirmamos sôbre a coisa, abandonada ou sem dono, com intenção de incorporá-la ao nosso patrimônio.

É método originário de aquisição, uma vez que inexiste transmissão do antigo dono para o ocupante. Êste, por ato próprio, faz seu o objeto, que não lhe é transmitido por ninguém. 
Assim, como exemplifica Torrente (Manuale di Diritto Privato, pág. 47), o pescador, que faz seus os peixes apanhados pela rêde, opera aquisição a título originário. De fato, antes de ser apreendido, o peixe era coisa de ninguém (res nullius).

O Código Civil individualizou quatro modos de ocupação: a caça (artigos 594 a 598), a pesca (artigos 599 a 602), a invenção (artigos 603 a 606) e o tesouro (artigos 607 a 610$)$.

\section{Da invenção.}

Restringir-nos-êmos, por ora, aos dois últimos apenas, invenção e tesouro. Dentro da melhor técnica, a primeira não pode ser havida como modo de adquirir coisas móveis.

Efetivamente, que vem a ser invenção? E achado de coisa alheia, perdida ou extraviada. Aquêle que acha, isto é, o inventor, não pode guardar para si o objeto que encontrou. Tem êle obrigação de restituí-lo.

A invenção é, portanto, relação jurídica, de que nascem direitos e obrigações para o inventor (obrigação de restituir e direito de ser recompensado).

O Código Civil inclui a invenção entre os modos de ocupação exclusivamente porque gera êsse direito à recompensa.

Preceitua realmente o artigo 603 que "quem quer que uche coisa alheia perdida, há de restituí-la ao dono ou legítimo possuidor".

Acrescenta o § único que "não o conhecendo, o inventor fará por descobri-lo, e, quando se lhe não depare. entregará o objeto achado à autoridade competente do lugar".

Tais preceitos impõem ao indivíduo determinado comportamento positivo em face de um direito real alheio. Como lembra BeTtr (Teoria Generale delle Obbligazioni, pág. 14), trata-se de exceção à regra do dever geral de abstenção. 
De feito, duas são as características dos direitos reais. Exercem-se contra todos e a êsse poder corresponde obrigação geral e negativa. Geral, porque todos, indistintamente, lhes devem respeito, todos os devem observar. Negativa, porque não exige a prática de ato algum, como nos direitos pessoais, em que o devedor sujeito está à prestação em favor do credor.

Entretanto, no caso específico da invenção, em que se acha em jôgo um direito real, a lei não se contenta com a obrigação negativa e impõe ao inventor um comportamento positivo e específico - a restituição da coisa achada.

Quando conhecido o dono, pràticamente não há problemas. Mas, tudo se complica quando êsse dono não aparece, o que amiúde ocorre, recordando Sílvio Rodrigues (Direito das Coisas, pág. 213), o caso de nossos dias. em que um comerciante comprou como sucata os restos de um avião destroçado por acidente, entre os quais encontrou valioso brilhante, que jamais foi reclamado.

A não restituição do objeto achado constitui delito. que o Código Penal, prestes a perder sua vigência, reprimia no artigo 169, § único, n. ${ }^{\circ}$ II, e que o nôvo, promulgado através do Decreto-Lei n. ${ }^{\circ}$ 1.004, de 21-10-1969, e a entrar em vigor a $10^{\circ}$ de agôsto próximo, também reprime no artigo 181, único, n. ${ }^{\circ}$ II (apropriação de coisa achada), bem como o Código Penal Militar (Decreto-Lei n. ${ }^{\circ} 1.001$. da mesma data, artigo 249 , $\S$ único).

À obrigação de restituir, corresponde o direito do inventor a recompensa. Edita realmente o artigo 604 do Código Civil: "o que restituir a coisa achada, nos têrmos do artigo precedente, terá direito a uma recompensa e à indenização pelas despesas que houver feito com a conservação e transporte da coisa, se o dono não preferir abandoná-la".

Não fixa o Código o quantum dessa recompensa, que será, destarte, de comum acôrdo, combinado entre as 
partes. Na falta de concordância, estima-lo-á a autoridade judiciária, com o seu prudente arbítrio.

O direito à recompensa existe sempre, ainda que não apareça o dono, ou ainda que êste resolva abandonar a coisa. como a lei lhe faculta. De fato, o legislador concede ao dono uma faculdade: a de abandonar a coisa achada, liberando-se, por essa forma, da obrigação de pagar a recompensa.

No artigo 606, determina o Código que "decorridos seis meses do aviso à autoridade, não se apresentando ninguém que mostre domínio sôbre a coisa, será esta vendida em hasta pública, e, deduzidas do preço as despesas, mais a recompensa do inventor, pertencerá o remanescente ao Estado, ou ao Distrito Federal, se nas respectivas circunscrições se deparou o objeto perdido, ou à União, se foi achado em território ainda não constituido em Estado".

Alguns Códigos atribuem o domínio ao inventor, desde que não apareça o verdadeiro dono, dentro de certo prazo. Nosso ordenamento jurídico optou, todavia, por critério diferente, e o Código de Processo Civil nos artigos 591 a 594, regula o procedimento a adotar-se quanto ao destino dos bens vagos.

Desejo ainda esclarecer que sôbre achado de documento sigiloso extraviado, dispõe o recente Decreto Federal n. ${ }^{\circ}$ 60.417, de 11-3-1967, artigo 66.

A exposição que acabo de fazer não ficaria completa, se não aludisse às epaves, que, no velho direito francês. pertenciam ao rei, ou aos juízes superiores - seigneurs justiciers (RugGiero, Instituições de Direito Civil, 2/373).

Desçamos, no entanto, a alguns aspectos curiosos. Desde a mais remota antigüidade, considerou-se como dever de humanidade e justiça o respeito às épaves, provenientes dos naufrágios. Entre os romanos, quem se apropriasse de qualquer objeto, advindo de navio em 
perigo, ou mesmo naufragado, adstrito estava a restituir o quádruplo. Penas ainda mais severas vieram a ser cominadas por Antonino. Mas, tão sábios e salutares preceitos foram em seguida violados pelos próprios imperadores.

Na Idade Média, as épaves foram consideradas res nullitus e o senhor da costa se julgava no direito de apoderar-se delas. Mais ainda: o desesperado desêjo de enriquecer-se a tal ponto corrompeu as criaturas, que os senhores da costa chegavam a acender, perto de determinados rochedos, fogos enganadores, a fim de provocar o naufrágio. Ou então subornavam pilotos para conduzirem as embarcações a lugares perigosos, com êles partilhando o produto das épaves.

As leis de Oberon cominaram penas contra êsse crime execrável e a Igreja condenou com anátemas aquêles que se apropriassem de coisas oriundas de naufrágios.

Os primeiros temperamentos de eqüidade são encontrados nos estatutos das cidades italianas. Para os de Trani, as épaves só se consideravam abandonadas depois de certo prazo. Para os de Pisa e Rimini, a obrigação de assistência aos náufragos se transformou em verdadeiro dever jurídico.

Contudo, como adverte Frone (Nouveau Droit International Public, 2. ${ }^{a}$ ed., 1/543), só depois que o Estado moderno se ergueu sôbre as ruínas do feudalismo e que leis de interêsse dos povos e da humanidade se sucederam às inspiradas em interêsses fiscais dos senhores feudais, é que cessou o abuso.

Entre nós, o Decreto-Lei n. ${ }^{\circ} 37$, de 18-11-1966, que dispõe sôbre o impôsto de importação, prescreve, no artigo 55: "a mercadoria lançada às costas e praias interiores, por fôrça de naufrágio das embarcações ou de medidas de segurança de sua navegação, e a que seja recolhida em águas territoriais, deverá ser encaminhada à repartição aduaneira mais próxima". Acrescenta o pará- 
grafo primeiro que se aplica à norma dêsse artigo "à mercadoria lançada ao solo ou às águas territoriais, por aeronaves, ou nestas recolhida, em virtude de sinistro ou pouso de emergência". Preceitua ainda o artigo 57 que "a pessoa que entregar mercadoria nas condições dêste Capítulo fará jus a uma gratificação equivalente a $10 \%$ do valor da venda em hasta pública". Pelo direito comercial, de um modo muito geral, os navios salvados dos naufrágios e outros inventos marítimos, devem ser arrecadados pelas autoridades do lugar aonde arribaram ou deram à costa e, na falta de reclamante, devem ser arrematados, sendo o produto líquido consignado em depósito para se restituir ao seu dono, quando aparecer (Almachio Diniz, Direito das Coisas segundo o Código Civil Brasileiro, 2. ${ }^{\text {a }}$ ed., pág. 160; Código Comercial, artigos 731 e seguintes; Código de Processo Civil, artigos 769 e seguintes).

\section{Do Tesouro.}

Eis aí instituto bastante controvertido, seja pelas suas vicissitudes históricas, seja pela sua construção dogmática. Como ensina Bonfante (Corso di Diritto Romano, 2/95), há quem o tenha considerado profundamente ilógico, digno, pois, de ser cancelado da legislação. Mas, as críticas, senão injustas, pelo menos são exageradas.

Existe, a respeito, verdadeira oposição entre a sociedade antiga e a moderna. Em sentido específico, o verdadeiro tesouro corresponde a uma sociedade e a uma economia rudimentares, de um tempo em que as guerras e as convulsões impunham ocultação das riquezas. A inexistência de estabelecimentos de crédito determinavam aquela ocultação. $O$ esconderijo constituía a caixa-forte de então. Mas, se o proprietário assim conseguia salvar suas riquezas, nem sempre lograva salvar-se a si mesmo, sem tempo para revelar a outrem o esconderijo. 
À mente, volvem então as estórias que ouvíamos em nossa infância, vinculadas às casas mal-assombradas, que guardavam o segrêdo de tesouros escondidos, cujo dono ansiava por revelá-los. É sempre o apólogo do velho moribundo e do imaginário tesouro oculto na vinha e que mostra como tal situação era familiar ao espírito antigo.

Que é um tesouro, econômicamente falando, pergunta Sá Pereira (Ob. cit., 8/355) ? É muita coisa e não é nada. Muita coisa, se o descobrimos e o pomos a circular. Então udquire êle valor econômico, ocupa um lugar no patrimônio. Nada, porém, se fica soterrado ou oculto.

De vez em quando, os jornais noticiam o encontro de um tesouro. Nas minhas fichas, deparo, por exemplo, notícia estampada no O Estado de São Paulo, de 16-6-1959, segundo a qual, no município de São Fidelis, Estado do Rio de Janeiro, ao abrir alicerces para nova construção. um operário encontrou caneca, contendo 93 libras ouro, cunhadas em 1851.

O têma sempre fascinou os escritores, como atestam os livros As Minas de Salomão de Rider Haggard, na primorosa tradução de EĢA DE QueIroz, e $O$ Tesouro de Cavendish, de Paulo Setúbal, inclusive os cinegrafistas (Cidade Submersa e Tesouro de Serra Madre).

Em meu livro sôbre Direito das Coisas, pág. 182, assim defino o tesouro, do ponto de vista jurídico: "o depósito oculto de moedas ou coisas preciosas, de cujo dono não se guarda memória". Apoio-me no conceito de Paulo (Digesto, Livro 41, Título I, Fragmento 31, parágrafo $1 .^{\circ}$ ) Thesaurus est vetus quaedam depositio pecuniae, cujus non extat memoria, ut jam dominum non habeat.

De conformidade com o artigo 607 do Código Civil, "o depósito antigo de moeda ou coisas preciosas, enterrado, ou oculto, de cujo dono não haja memória, se alguém casualmente o achar em prédio alheio, dividir-se-á por igual entre o proprietário dêste e o inventor" 
São requisitos dêsse modo de adquirir o domínio, incluído pela antiga doutrina na acessão: a) - tratar-se de depósito antigo de moedas ou objetos preciosos, como vasos e jóias; b) - não restar memória de seu dono; c) - estar oculto ou enterrado; d) - ser casual a invenção.

Em primeiro lugar, preciso é se trate de depósito antigo de moedas ou objetos preciosos, como vasos e jóias. Realmente, a coisa há de ser móvel. Portanto, não pode ser havido como tesouro o que se ache incorporado ao solo, como a mina ou a jazida, e que compartilhe, pois, da natureza imóvel.

Em segundo lugar, importa que não haja memória de seu dono. Tesouro tem de ser res sine domino. Esclarece o artigo 610 do Código Civil que “deixa de considerar-se tesouro o depósito achado, se alguém mostrar que lhe pertence".

Em terceiro lugar, o depósito há de se achar oculto ou enterrado. Sustenta CLóvis (Código Civil, 3/138), que se não considera tesouro o achado de objetos preciosos nos escaninhos de um móvel. Pela mesma razão, não seria também tesouro o achado de valôres dentro das páginas de um livro. Explica o eminente civilista pátrio que assim acontece porque a ocultação não se reveste da indispensável vetustez, necessária a caracterizar o tesouro, não sendo difícil, destarte, identificar-lhe o dono. Mas, tal opinião foi vantajosamente refutada por Sá Pereira (Ob. cit., pág. 358), o qual demonstrou a possibilidade de achado de tesouro hàbilmente escondido em móvel de tal antigüidade. que problemática se tornaria a individualização do dono. Acrescente-se ainda que não pode ser havido como tesouro o que se encontre na superfície. Nesse caso, será um objeto perdido ou extraviado, não um tesouro no sentido jurídico. De modo idêntico, o encontrado no ôco de uma árvore, dentro de lata enferrujada (Revista Forense, 55/338).

Por fim, preciso se torna seja casual a invenção. Por conseguinte, inexistirá direito ao prêmio na hipótese em 
que o inventor, intencionalmente, sem autorização, penetra em prédio alheio para realizar a pesquisa. Com a invasão do imóvel o inventor pratica ato ilicito, de que direito algum pode advir.

A lei prescreve que o tesouro seja dividido por igual entre o proprietário do imóvel e o inventor (artigo 607, in fine). No regime mais antigo, o tesouro era, por inteiro, do proprietário do solo. Era a velha atração do dominium romano. Em polo oposto, chegou a ser atribuido por inteiro ao inventor.

O Código Civil Brasileiro determina a partilha entre ambos. Ganha o proprietário do solo porque tem o domínio dêste, como extensão de seu direito dominial. Ganha, outrossim, o inventor, como prêmio, por haver restituído à economia social uma coisa esquecida (SÁ PEREIRA, 8/360).

Se o que o achar fôr o senhor do prédio, algum operário seu, mandado em pesquisa, ou terceiro não autorizado pelo dono do prédio, a êste pertencerá por inteiro o tesouro (artigo 608). O tesouro corresponde a um acessório do solo, a que adere. Por isso, pertence ao dono respectivo, se êste descobre - o por si, ou através de operário especialmente encarregado da busca. Mas, se entregue a outro serviço, casualmente o descobre o operário, terá direito à metade. Se vários operários o descobrem, fará jus ao prêmio aquêle que primeiro avistou ou topou com o tesouro. Relativamente ao terceiro, o Código mostra-se ambíguo. Contudo, o pensamento do legislador é o seguinte: direito ao tesouro êle não tem se, deliberadamente, se entrega à sua pesquisa. Merecê-lo-á, todavia, pela metade, se acidentalmente o encontra.

Se se tratar de terreno aforado, partir-se-á o tesouro, igualmente, entre o inventor e o enfiteuta, ou será dêste por inteiro, quando êle mesmo seja o inventor (Código Civil, artigo 609). O usufrutuário, por sua vez, não tem direito à parte do tesouro achado por outrem (artigo 727). 
O sistema do Código, portanto, é êste: na enfiteuse, o senhorio direto não aufere parcela alguma; e na enfiteuse, quem é excluído é o usufrutuário, cabendo o direito ao nu-proprietário.

Ad instar do que ocorre com a invenção, constitui crime a apropriação do tesouro, quer em face do antigo Código Penal (artigo 169, § único, n. ${ }^{\circ} \mathrm{I}$ ), quer em face do nôvo (Decreto-Lei n. ${ }^{\circ}$ 1.004, de 21-10-1969, artigo 181, \& único, $\left.n .^{\circ} \mathrm{I}\right)$.

Pela sua analogia com a matéria que ora estamos a cuidar, interessa igualmente falar dos tesouros no fundo do mar. De fato, imensas riquezas esconde o fundo do mar, provenientes dos naufrágios. Refere a Enciclopédia Espasa que só defronte ao pôrto de Nova Yorque, num raio relativamente pequeno, submersas se acham riquezas num valor superior a vinte bilhões de pesetas.

Por exemplo, defronte a Hell Gate, jaz a fragata inglesa Hussar, afundada a menos de sessenta metros e que encerra em seu bojo vinte e cinco milhões de pesetas-ouro. A duzentos metros da Hussar se encontra o Lexington, que trazia de Vera Cruz quatro mil quilos de prata fina, meia tonelada de ouro e quinhentas mil piastras mexicanas. 0 Lusitânia, que jaz a oitenta e dois metros de profundidade, guarda no seu interior cinco milhões de pesetas, e o Ocean, que conduzia para a China parte do empréstimo, que lhe fôra concedido, afundou com vinte e cinco milhões de pesetas.

Entre nós, é conhecido o caso daquele navio pirata, que naufragou no pôrto de Paranaguá e que tem sido objeto de ingentes pesquisas por parte de um patrício, aliás, advogado de São Paulo. Se o tesouro vier a lume, a quem pertencerá? O problema jurídico já foi levantado, tendo-se sustentado que o mesmo pertencerá à União.

Também oferece conexões com o nosso estudo os vários tesouros perdidos, como o dos Incas, o do El Dorado e o de Lobengula. O primeiro foi escondido durante a con- 
quisla pelos espanhóis. Destinava-se ao resgate de Atahualpa e foi enterrado quando os incas se inteiraram de que seu soberano já havia sido morto. Deveria ser conduzido por doze mil lhamas e o seu pêso era de seiscentas toneladas. Jamais foi encontrado.

O de El Dorado teve sua tradição divulgada pelos conquistadores espanhóis, que mencionaram uma laguna sagrada da Guatemala, em que se guardariam incalculáveis riquezas do "homem dourado". Os espanhóis inùtilmente tentaram esvaziar a laguna, sendo realmente encontrados alguns objetos de grande valia.

O de lobengula é outro tesouro que se perdeu. Constituía-se de marfim e diamantes, em tal quantidade que, segundo a tradição, daria para encher dez vagões.

Poderíamos aludir ainda ao de Rhampsinit, mencionado por Herodoto, mas ficamos por aquí. Já não estamos mais na ciência do direito, porém, em pleno domínio da fantasia. Cessa, portanto, a palavra do jurista, para que outrem, isto é, o escritor, retome o assunto, tão cheio de fascínio e de mistério. 